\title{
White clover seed inoculation and coating in New Zealand
}

\author{
W.L. LOWTHER ${ }^{1}$ and G.A. KERR ${ }^{2}$ \\ ${ }^{1}$ Retired, 101 a Forfar St, Mosgiel, Dunedin 9024 \\ ${ }^{2} \mathrm{NZ}$ Agriseeds Ltd, 2547 Old West Coast Rd, RD1 Christchurch 7671 \\ gak@agriseeds.co.nz
}

\begin{abstract}
This paper reviews the requirement for inoculation of white clover (Trifolium repens) seed with rhizobia bacteria in New Zealand. The pastoral industry relies on the nitrogen fixed by clover's rhizobia bacteria. These rhizobia were not present in soils prior to European settlement, but were introduced as contaminants, and naturally spread with pastoral development. The advent of large scale land development in the 1950s identified areas where clovers failed to nodulate and establish due to the absence of rhizobia, which led to the development of inoculated lime coated seed. Rhizobia have spread widely throughout New Zealand, and in the great majority of situations where pasture is being sown, soils now contain high levels of resident rhizobia capable of nodulating white, red and alsike clover, and inoculation of clover seed is not required. However, it is suggested the use of inoculated clover seed should be considered in the following three situations as an insurance against nodulation failure: undeveloped grasslands with no evidence of resident clover; virgin pastoral land cleared directly from scrub; and paddocks cropped with maize continually for over 10 years. It has been hypothesised that inoculating clover seed may improve clover growth through introducing more effective rhizobia with better nitrogen fixation ability, but the research in this area suggests there is little likelihood of any significant response from doing this.
\end{abstract}

Keywords: rhizobia, inoculation, coated seed, white clover, red clover, alsike clover

\section{Introduction}

A cornerstone of New Zealand's internationally competitive agriculture industry is the ability of clover, particularly white clover (Trifolium repens), to fix atmospheric nitrogen into plant available forms. This occurs through a process where soil bacteria, rhizobia, invade the roots of the legume plant and form root nodules in which the nitrogen conversion occurs. Rhizobia that nodulate clovers are not native to New Zealand, and were introduced accidentally with the onset of European settlement (Greenwood 1965). It is presumed that they were introduced by chance in soil and dust attached to equipment, plant material, seed and stock hooves. There is little mention in early literature about any need to inoculate clovers, and Saxby (1940, 1956) did not refer to it for pasture establishment. The need for inoculation only became apparent when large scale land development was initiated on land cleared out of scrub and bush in the 1950s (Sears et al. 1955; Greenwood 1961; During et al. 1962).

Rhizobia were undetected in undisturbed gumland soils by Greenwood (1961), detected in low levels in soils cultivated out of scrub by Gould et al. (1968), and found to be patchy and variable in numbers in soils of the North Island hill country (Greenwood 1965; MacFarlane \& Bonish 1986).

The absence of clover rhizobia and hence the failure of clover to nodulate and survive in extensive areas of the tussock grasslands, is a probable explanation for the emphasis on cocksfoot (Dactylis glomerata) in early oversowing reports (Sewell 1950, 1952). Reynolds (1957) obtained excellent clover establishment without inoculation, in trials close to roads, which led him to erroneously conclude inoculation was not required in the Mackenzie Basin. Similarly, Ludecke \& Leamy (1972) concluded that inoculation was not necessary on the drier lower and mid-altitude tussock grasslands soils. However, trials in more isolated areas showed rhizobia were needed (Smeatham 1966; Adams 1964) and inoculation became a standard recommendation (White 1966). Surveys of clover rhizobia distribution in the tussock grasslands by Gaur \& Lowther (1980), explained the reasons for the different trial responses to inoculation. Clover rhizobia were absent from large areas of the tussock grasslands but were present in some soils, particularly low altitude dry soils where haresfoot clover (Trifolium arvense) was present. Rhizobia that nodulate haresfoot clover also nodulate white clover (Greenwood 1965). Clover rhizobia populations of up to 4000 per gram of soil were detected in $40-60 \%$ of tussock grasslands soils, even in the absence of naturalised clovers, which confirms the ability of clover rhizobia to colonise and persist in the soil even in absence of a host legume (Greenwood 1965). Survey results of Gaur and Lowther (1980) were the basis for the recommendation to inoculated clover seed oversown onto tussock grassland soils unless there was a uniform cover of haresfoot or other clovers (Lowther \& Patrick 1994). 
It is important to note that the results from gumland, hill country and tussock grasslands only directly apply to oversowing, as in cultivatable land Greenwood (1961) and Gould et al. (1968) showed rhizobia levels could be increased from low or undetectable levels simply through cultivation and application of lime.

Populations of $>100,000$ clover rhizobia per gram of soil have been shown to occur in pastoral soils (Hale 1980, 1981; Gaur \& Lowther 1980; Patel \& Lambert 1985; Elliot 1997), and once established in the soil, rhizobia can survive in the absence of clover as long as soil conditions, particularly soil $\mathrm{pH}$, are suitable (Greenwood 1965). Populations of clover rhizobia have been shown to be higher in the rhizosphere of clover roots that in the surrounding soil (Pryor \& Crush 2006).

In tandem with rhizobial research, development of lime-based seed coating was carried out through the 1950 s, 1960s and 1970s, as a means of improving the delivery of rhizobia, particularly for aerial oversowing (Hastings \& Drake 1962, 1963; Hale et al. 1979; Taylor \& Lloyd 1968; Lowther \& McDonald 1973; Lowther \& Bonish 1980).

\section{Rhizobia under continuous cropping}

Rhizobia can survive for long periods under cropping. For example in Britain significant numbers of clover rhizobia were found after 125 years of continuous wheat (Nutman 1969).

In New Zealand it has been suggested that maize cropping, particularly with an accompanying drop in soil $\mathrm{pH}$, could be detrimental to rhizobia survival (Bonish \& Steele 1985). In Poverty Bay, uninoculated white clover failed to establish in a paddock resown to pasture after 15 years of maize crops. Tests showed very low numbers of rhizobia $(<10$ per gram soil) and resowing with inoculated seed resulted in successful establishment. Unfortunately no soil $\mathrm{pH}$ data is available. In an intensive survey of maize paddocks Bonish \& Steele (1985) failed to find any field where clover rhizobia could not be detected, even after 32 years of continuous maize, with rhizobia adequate for nodulation ( $>360$ per gram soil) in the Manawatu, Bay of Plenty and Waikato soils following 6, 5 and 15 years of continuous cropping. In the Bay of Plenty, four paddocks had low numbers of clover rhizobia $(<100$ per gram soil); three of the paddocks had been in maize for over 15 years, the fourth paddock only for 4 years but had a soil $\mathrm{pH}$ of 5.2. Bonish \& Steele recommended sowing inoculating clover seed into soil which had been continuously in maize for 10 years or more, or in which $\mathrm{pH}$ had fallen under 5.5. This recommendation is conservative, and should be interpreted as such for two reasons. Firstly, samples were taken before cultivation and fertilisation with lime, which Greenwood (1961) demonstrated can produce high populations of rhizobia. Secondly, there is no evidence that a population of 14 rhizobia per gram soil would be too low to ensure nodulation. For example, all seedlings of Maku lotus (Lotus uliginosus) nodulated when sown into soil with 15 rhizobia per gram (Lowther \& Patrick 1993).

\section{Nitrogen fixing effectiveness}

In his review of rhizobia, Greenwood (1965) identified that strains vary in their nitrogen fixing effectiveness, that is the amount of nitrogen they can fix, with white clover. Table 1 summarises results from 10 studies across a range of New Zealand soils. There was a wide range of nitrogen fixing effectiveness of the strains, and in all but one study (Hale 1980) strains were

Table 1 Number and nitrogen fixing effectiveness of clover rhizobia in New Zealand soils compared to commercial inoculant strains ( 1 Gaur \& Lowther (1980), ${ }^{2}$ Pankhurst \& Greenwood (1983), ${ }^{3}$ Macfarlane \& Bonish (1986), ${ }^{4}$ Rys \& Bonish (1981), ${ }^{5}$ Hale (1981), ${ }^{6}$ Hale (1980), ${ }^{7}$ Patel \& Lambert (1985), ${ }^{8}$ Elliot (1997)).

\begin{tabular}{|c|c|c|c|c|}
\hline Area & Situation & No per g soil & $\begin{array}{l}\text { Effectiveness } \\
\text { (\% of inoculant strain) }\end{array}$ & $\begin{array}{l}\text { Mean } \\
\text { (\% of inoculant strain) }\end{array}$ \\
\hline Otago $^{1}$ & $\begin{array}{l}\text { Unimproved, } \\
\text { no clover }\end{array}$ & $<4-10^{3}$ & * & * \\
\hline Otago $^{1}$ & $\begin{array}{l}\text { Unimproved, } \\
\text { Haresfoot clover }\end{array}$ & $10^{2}-10^{5}$ & $7-120$ & 67 \\
\hline Otago $^{1}$ & Ex pasture & $10^{6}$ & $8-117$ & 83 \\
\hline Manawatu $^{2}$ & Ex pasture & $10^{5}$ & $24-109$ & 70 \\
\hline Waikato $^{3}$ & Ex scrub & $10-10^{4}$ & $0-120$ & * \\
\hline Taranaki $^{4}$ & Pasture & $10^{4}-10^{6}$ & $50-109$ & 79 \\
\hline Waikato $^{5}$ & Pasture & $10^{4}-10^{6}$ & $31-85$ & 69 \\
\hline Waikato $^{6}$ & Ex pasture & $10^{3}-10^{4}$ & * & 74 \\
\hline Manawatu $^{7}$ & Pasture & * & $3-170$ & 76 \\
\hline Canterbury $^{8}$ & Ex pasture & $10^{5}$ & $0-120$ & 75 \\
\hline
\end{tabular}


found that were similar to, or more effective than the commercial inoculant strains. The mean effectiveness of strains from the different experiments was relatively similar, ranging from $69 \%$ to $85 \%$ of the inoculant strain. Gaur \& Lowther (1980) found one site with a mean effectiveness of $93 \%$, which they attributed to the spread of rhizobia from an adjacent area oversown with inoculated clover seed several years beforehand.

\section{Strains of rhizobia for inoculants}

Before 1955 inoculants available in New Zealand were mainly for lucerne (Medicago sativa), but by 1957 clover inoculants were readily available (Cunningham 1957). Strains recommended for use in New Zealand manufactured inoculants were PDDCC 2666, 2668 and 2153, while strain CC 275e was recommended for Australian inoculants sold in New Zealand. When oversown, the percentage of seedlings nodulated ranged from $40-49 \%$ when inoculated with these strains, compared to only $17 \%$ with the Australian inoculant strain TA1 (Lowther \& Johnstone 1978). The low nodulation from TA1 was attributed to its poor survival on the seed before, or on the soil surface after, oversowing. Following the demise of the New Zealand inoculant manufacturing industry, CC $275 \mathrm{e}$ became the Australian inoculant strain used in New Zealand. Although CC275e has been shown to fix more nitrogen with white clover than TA1 (Brockwell \& Gibson 1968) and to be more competitive and persistent (Brockwell et al. 1972), TA1 has remained the recommended strain for white clover in Australia.

The majority of research into rhizobia strains in New Zealand was undertaken with the white clover cultivar 'Grassland Huia', and there is no guarantee that these strains are the most effective for other white clover cultivars (Bonish 1980), as cultivars vary in their relationship with different strains (Sherwood \& Masterson1974; Harrison et al. 1989).

\section{Seed coating}

Lime coating of inoculated clover seed was developed in Australia to reduce the amount of lime fertiliser required for nodulation and establishment of clover (Loneragan et al. 1955), but it became apparent that lime could also enhance the survival of rhizobia on seed. Hastings \& Drake $(1962,1963)$ investigated a range of materials for their effect on rhizobia survival and promoted the use of methyl cellulose as an adhesive and gafsa-phosphate/dolomite as a coating material. These proved satisfactory for cultivated soils (Greenwood 1961), but ineffective for oversowing (Cullen \& Ludecke 1966). Improvements in the standard of New Zealand inoculants (Lowther 1974a), identification of gum arabic (Lowther 1975b) and lime (Lowther 1975b;
Lowther \& Johnstone 1979) as more effective coating materials, improvements in inoculant formulation (Hale et al. 1979), and introduction of vacuum drying in the commercial coating process (Taylor \& Lloyd 1968) resulted in pellets that gave better establishment of oversown clover than that obtained from freshly inoculated seed (Lowther \& McDonald 1973; Lowther $\&$ Bonish 1980). Although establishment was often less than that from the small quantities of seed inoculated and lime coated in the laboratory for trials, this was not practical for farmers.

Molybdenum is essential for nitrogen fixation, and in view of the possible uneven distribution of molybdenum in fertiliser (Lipsett \& David 1977), and uneven distribution of aerially applied fertiliser (Scott \& Grigg 1970), the addition of molybdenum to seed has been recommended as a means of ensuring it is in the vicinity of the establishing seedling (Gault \& Brockwell 1980). Gault \& Brockwell cautioned the use of soluble molybdenum compounds (e.g. sodium molybdate) because of possible reduced survival of rhizobia, however Lowther (1987) found no detrimental effect from applying sodium molybdate to coated seed, which he attributed to the low rate of molybdenum used. For molybdenum deficient soils, the inclusion of molybdenum in coated seed became a standard recommendation (Lowther \& Patrick 1994).

Because of the widespread sulphur deficiency in the tussock grasslands, including this in seed coating was suggested. In trials where basal superphosphate was applied, establishment from gypsum coating was similar to lime coating on the driest site, but consistently lower on the other sites (Lowther 1977; Lowther \& Johnstone 1979). In the absence of basal sulphur fertiliser, gypsum coating increased seedling establishment compared to lime coating, but the small amount of sulphur in the seed coat had little effect on clover growth. Although the effect from sulphur coating was only small, Scott \& Archie (1978) recommended elemental sulphur be added to lime coated clover seed.

Seedling predation by native insects can seriously reduce the establishment of white clover oversown on tussock grassland soils, and this can be markedly reduced by the inclusion of systemic insecticide in the seed coat (Barratt et al. 1995). The use of commercial coated seed incorporating a systemic insecticide became a standard recommendation for oversowing (Lowther \& Patrick 1994).

White clover seedling vigour can be reduced by clover cyst (Heterodera trifolii) and root-knot nematodes (Meloidogyne sp.) and this can affect establishment success (Watson 1990). Pesticides have been formulated as seed coatings to provide seedling protection to white clover from root knot and clover 
cyst nematodes with variable results (Barker et al. 1993).

\section{Soil $\mathrm{pH}$ and lime}

Soil acidity has a major effect on white clover through adversely affecting rhizobia survival, nodulation and plant growth. These effects can operate directly through $\mathrm{pH}$, or through calcium deficiency, or aluminium and manganese toxicity. Because of the complexity of soil acidity it is difficult to ascribe precise $\mathrm{pH}$ limits for white clover, however to overcome any potential effects a soil $\mathrm{pH}$ of 5.8 to 6.0 is recommended (Edmeades et al. 1983).

Early research by Loneragan \& Dowling (1958) demonstrated the nodulation process was more sensitive to low $\mathrm{pH}$ and calcium deficiency than was either rhizobia survival or clover growth. Seed coating with lime was developed as a means of raising the $\mathrm{pH}$ and supplying calcium in the vicinity of the plant root to allow nodulation to occur (Loneragan et al. 1955).

In early New Zealand trials, lime coating of clover seed was ineffective (Cullen \& Ludecke 1966; Adams \& Lowther 1970) due to the poor quality inoculants and coating materials (Lowther 1975b). Once these problems were overcome, the ability of lime coating to promote nodulation on low $\mathrm{pH}$ soils was important in the development of acid soils where it was not economic to broadcast lime. In glasshouse trials on tussock grassland soils, lime pelleting was compared with applying lime to the top $1 \mathrm{~cm}$ of soil, to simulate aerial application. Lime coating seed replaced the requirement for lime $(2500 \mathrm{~kg} / \mathrm{ha})$ on soils with a $\mathrm{pH}$ as low as 4.7 (Lowther 1974b), and importantly, lime coating not only increased nodulation on roots in the top $1 \mathrm{~cm}$ but also throughout the pot, indicating that once nodulation is initiated it can continue in acid soils. A similar result was obtained in an oversowing trial on an acid ( $\mathrm{pH} 4.8$ ) tussock grassland soil (Lowther 1975a).

Replacing lime applications with the use of lime coating of clover seed should not be extrapolated to cultivated situations. Where acid soil conditions were ameliorated by cultivating lime into the soil, clover yields responded to high rates of lime even where seed was lime coated (Lowther unpub.).

\section{Commercial seed coating}

In the 1970s the Government set up a voluntary testing service ("The Inoculant and Coated Seed Testing Service") and commercially inoculated and coated seed purchased by Government Departments had to meet a required standard of at least 300 viable rhizobia per seed after storage at $20^{\circ} \mathrm{C}$ for 28 days after manufacture (Anon 1979a,b). This standard was based on laboratory and field tests (Lowther \& Bonish 1980; Bonish et al. 1980).
There is little published information on the current standard of commercially coated seed in New Zealand. Inoculation of white clover has always been recognised as difficult, as once applied to the seed rhizobia can die rapidly, particularly by desiccation during the first few hours on the seed. After this rapid death there is a continual slow decline. Death rate is particularly affected by high temperature during both manufacture and storage.

\section{Introduction of effective rhizobia}

The use of inoculated, coated clover seed to introduce rhizobia with a higher nitrogen fixing ability than resident rhizobia has been suggested. Although increased nitrogen fixation has been achieved under experimental conditions, published results suggest that it is very unlikely to be achieved in normal farm situations with commercially inoculated coated clover seed.

Research in this area is complex, as different strains of rhizobia vary in their initial competitive ability (Roughly et al. 1976; Materon \& Hagedorn 1982: Ames-Gottfred \& Cristie 1989) and persistence (Gibson et al. 1975), and the competitive ability between strains can also be affected by host cultivar and site (Roughley et al. 1976).

Brockwell et al. (1975) demonstrated that the level of resident rhizobia can affect the competitiveness of introduced strains. Sowing seed inoculated with strain TA1 (with 135 rhizobia per seed) on a soil with few resident rhizobia (40 per gram), resulted in almost all nodules being occupied by TA1, however, on a soil with 10,000 resident rhizobia per gram, less than $10 \%$ of the nodules were formed by TA1. The results of Brockwell et al. (1972) on three different soils demonstrate the differences that can occur between rhizobial strains. On the two sites with low populations of resident rhizobia $(\leq 400$ per gram soil), strain CC275e still occupied at least $50 \%$ of nodules after three years, whereas the highest occupancy recorded for TA1 was $21 \%$ a year after sowing. On the site with a high resident rhizobia population (14,500 per gram soil) the nodule occupancy in the second year was only $27 \%$ for CC 275 e, and TA 1 was not detected.

Successful introductions of effective strains on soils with low populations of resident rhizobia have been achieved when the inoculant outnumber resident rhizobia by around 10-fold (Weaver \& Frederick 1974 ) to 100-fold (Ireland \& Vincent 1968; Materon \& Hagedorn 1982). Effective rhizobia have been successfully introduced into UK low-fertility peat or peaty podzol soils where strains ineffective on white clover are widespread (Holding \& King 1963). However, even on these soils responses to inoculation were inconsistent and only occurred where the 
inoculant strains form $>50 \%$ of the nodules (Newbould et al. 1982).

In their review, Brockwell \& Bottomley (1995) concluded that with conventional seed inoculation techniques it is not possible to introduce more effective strains of rhizobia unless the resident population is very low $(<1000$ per gram soil $)$ and ineffective on clover. Even in this situation effects are expected to be transitory. Given populations of $>100,000$ clover rhizobia per gram of soil may occur under clover based pastures (Hale 1980, 1981; Gaur \& Lowther 1980; Patel \& Lambert 1985; Elliot 1997), the chance of any major strain change is low.

In view of the international research evidence, and that high populations of clover rhizobia occur in pastoral soils (Hale 1980, 1981; Gaur \& Lowther 1980; Patel \& Lambert 1985; Elliot 1997), it is not surprising that there are few reported experiments in New Zealand on the effect of inoculation in soils with resident rhizobia. Hale $(1980,1981)$ compared inoculating rhizobia directly into the soil and inoculating seed in short term pot trials. He demonstrated that clover growth could be increased if high concentrations of rhizobia were inoculated into the soil just prior to sowing, with the introduced rhizobia forming $49-87 \%$ of the nodules on the clover roots. However using seed inoculation, only 3-18\% (Hale 1980) and 7-38\% (Hale 1981) of the nodules on the clover roots were formed by the inoculant strain, and there was no increase in plant growth. In North Island field trials on four different soils, the slurry inoculation of seed at the recommended rate resulted in only $1-9 \%$ of nodules being formed by the inoculant strain four months after sowing (Hale 1980). Pankhurst \& Greenwood (1983) found that the inoculant strain formed $27 \%$ of nodules 5 months after seed was sown into cultivated soil, but the percentage declined with time and no nodules containing the inoculant strain were detected 24 months after sowing. Pankhurst \& Greenwood also provide a good illustration of the problems with trying to introduce effective rhizobia. Nodules $<3 \mathrm{~cm}$ from the crown of the plant had $30 \%$ occupancy of the inoculant strain, nodules on lower roots had only $3 \%$ occupancy, while nodules on stolons had $7 \%$ occupancy. Macfarlane \& Bonish (1986) recommended inoculation of white clover sown into land cleared out of scrub because of the scattered and often low populations of resident rhizobia. They found two out of seven sites where inoculation had a significant effect on establishment because resident population were absent or very low. However, there was a rapid multiplication of resident rhizobia in the presence of the seedling white clover roots which resulted in a low recovery of inoculant rhizobia strain in the nodules.
Gaur \& Lowther (1982a,b) found a complex interaction between sowing method, inoculation rate, seed pelleting and rhizobia strain on the percentage of nodules occupied by the inoculant strain. Strains performed differently when inoculated seed was sown into cultivated soil or oversown. In a cultivated situation, strain PDDCC 2163 had no apparent effect on nitrogen uptake or clover growth, and nodule occupancy was only 8 to $32 \%$. The most competitive and persistent strain was PDD 4144, a New Zealand reisolate of TA1. This contrasts with overseas trials which have shown TA1 to be a poor competitor when inoculated onto white clover (Brockwell et al. 1972) and red clover (Trifolium pratense) (Materon \& Hagedorn 1982). When oversown on to a site with a resident population of haresfoot clover there was a significant increase in clover nitrogen uptake and clover growth after 15 months from seed inoculation with strain PDDCC 2163, surprisingly as the strain was detected in only $38 \%$ of the nodules in this treatment 6 months after sowing. There was a small further increase in clover growth from increasing the inoculation level to 10 times the recommended rate, and no apparent effect from lime pelleting even though the nodule occupancy at 6 months increased from 38\% to $57 \%$, and after 15 months was still $55 \%$. Caution must be used in attributing all the effect to competition with resident rhizobia as even though the area had an average resident population of $4.9 \times 10^{5} / \mathrm{g}$ field soil these may have been unevenly distributed as suggested by Macfarlane \& Bonish (1986). Strain PDDCC 2163 was recommended for use in New Zealand because of its good performance for oversowing onto tussock grasslands devoid of rhizobia (Lowther \& Johnstone 1978). There is no logical explanation for the enormous difference in nodule occupancy of PDDCC 2163 on the oversown versus cultivated sites, and given the contrast with the consensus of other published results, there are serious reservations about these results. In addition, these results were obtained with laboratory inoculated and coated seed with populations of rhizobia at sowing considerably higher than on commercially inoculated and coated seed.

There appears to be only one experiment where long term response to seed inoculation has been investigated (Brown 1996). This compared two paddocks in the Te Anau Basin resown with either bare or commercially inoculated and coated seed, and after three years there was no apparent difference in the distribution of symbiotic effectiveness of the rhizobia or in the proportion of strains genetically similar to the inoculant strain between the two paddocks. 


\section{Discussion}

One aim of this review was to provide evidence for the present need to inoculate white, red and alsike clover (Trifolium hybridum) in New Zealand. Because of its agricultural importance the majority of the research was carried out on white clover, but the same inoculant is used for red and alsike clovers.

Clover rhizobia have spread widely throughout New Zealand, and in the great majority of situations where pasture is being sown, soils now naturally contain high levels of resident rhizobia capable of nodulating clover, and inoculation of clover seed is not required. Rhizobia can survive many years in the soil even in the absence of clover, but it is suggested the use of inoculated and coated clover seed should be considered in the following three situations as an insurance against nodulation failure.

Firstly, in undeveloped grasslands with no resident clover (haresfoot, suckling (Trifolium dubium) or white). Although soil in much of these areas now contains clover rhizobia as a result of natural spread, there are still areas devoid of it, or where rhizobia distribution may be patchy.

Secondly, in virgin pastoral land cleared directly from scrub. This is a precautionary recommendation, as little survey work has been done since the 1980s.

Finally, in paddocks cropped with maize continually for over 10 years. This is also a precautionary recommendation following a clover establishment failure attributed to the absence of rhizobia in one paddock that had been in continuous maize for 13 years. A later survey of paddocks continually in maize detected rhizobia in all paddocks sampled, even after 32 years in maize, although numbers were sometimes low.

It has been hypothesised that inoculating clover seed may improve clover growth through introducing more effective rhizobia, however trial work suggests that the likelihood of any significant response from doing this, with our current technology, is very unlikely. Resident populations of rhizobia in New Zealand pastoral soils can be up to 1,000,000 per gram of soil (or 3,000,000 in a teaspoon of soil), within each soil there are a range of rhizobial strains which vary widely in their nitrogen fixation ability, and are well adapted to local conditions. Results show that the rhizobia from inoculated seed are likely to form such a small portion of nodules they will have little or no effect on clover growth. An additional factor is that clover cultivars have all been selected with existing soil populations of rhizobia, and there is no guarantee that the individual strain(s) used in a clover inoculant will be the most effective for any cultivar of white clover.

In addition to improving survival of rhizobia, there are some situations where seed coating can provide other advantages to clover establishment. Lime coating can enhance nodulation through a localised increase in $\mathrm{pH}$ on acid soils where it is uneconomical to broadcast lime. There is also considerable evidence to support the use of seed coating through both targeted application of fertiliser to enhance growth of the germinating seedling, and insecticide to help protect seedlings from pest damage.

\section{REFERENCES}

Anon. 1979a. The inoculant and coated seed testing service. Seed Testing Station, Palmerston North

Anon. 1979b. Purchase of seed for Government Departments. Seed Testing Station, Palmerston North

Adams, A.F.R. 1964. Observations on legume establishment and growth on acid soils. Proceedings of the New Zealand Grassland Association 26: 115122.

Adams, A.F.R.; Lowther, W.L. 1970: Lime, inoculation, and seed coating in the establishment of oversown clovers. New Zealand Journal of Agricultural Research 13: 242-251.

Ames-Gottfred, N.P.; Christie, B.R. 1989. Competition among strains of Rhizobium leguminosarum biovar trifolii and use of a diallel analysis in assessing competition. Applied and Environmental Microbiology 55:1599-1604.

Barker, G.M.; Addison, P.J.; Watson, R.N. 1993: Seed treatment for protection of seedling white clover from nematodes. Proceedings New Zealand Plant Protection Conference 46: 228-232.

Barratt, B.I.P.; Lowther, W.L.; Ferguson, C.M. 1995. Seed coating with insecticide to improve oversown white clover (Trifolium repens L.) establishment in tussock grasslands. New Zealand Journal of Agricultural Research 38: 511-518.

Bonish, P.M. 1980. Nodulation of white clover: plant influences on the effectiveness of Rhizobium trifolii. New Zealand Journal of Agricultural Research 23: 239-242.

Bonish, P.M.; Neville, F.J.; Lowther, W.L. 1980. Laboratory testing for numbers of viable rhizobia on commercially-pelleted legume seed. New Zealand Journal of Experimental Agriculture 8: 139-143.

Bonish, P.M.; Steele, K.W. 1985. Rhizobium populations in maize fields of the North Island, New Zealand. New Zealand Journal of Agricultural Research 28: 299-303.

Brockwell, J.; Bottomley, P.J. 1995. Recent advances in inoculant technology and prospects for the future. Soil Biology Biochemistry 27: 683-697.

Brockwell, J.; Gibson, A.H. 1968. Root-nodule bacteria for some cultivated species of Trifolium. Journal of the Australian Institute of Agricultural Science 34: 224. 
Brockwell, J.; Bryant, W.G.; Gault, R.R. 1972. Ecological studies of root-nodule bacteria introduced into field environments 3. Persistence of Rhizobium trifolii in association with white clover at high elevations. Australian Journal of Experimental Agriculture and Animal Husbandry 12: 407-413.

Brockwell, J.; Herridge, D.F.; Roughley, R.J.; Thompson, J.A.; Gault, R.R. 1975. Studies on seed pelleting as an aid to legume seed inoculation 4. Examination of preinoculated seed. Australian Journal of Experimental Agriculture and Animal Husbandry 15: 780-787.

Brown, S. 1996. Effect of inoculation on genetic diversity of white clover rhizobia from Te Anau pastures. AgResearch Summer Scholarship Report.

Cunningham, G.H. 1957. Certification of legume seed inoculants. New Zealand Journal of Agriculture 94: 578.

Cullen, N.A.; Ludecke, T.E. 1966. The effects of inoculation, pelleting, rate of lime and time of sowing on establishment of white clover. Proceedings of the New Zealand Grassland Association 28: 96-104.

During, C.; Cullen, N.A.; Bennett, G.M. 1962. The establishment of pasture on yellow-brown loams near Te Anau. New Zealand Journal of Agricultural Research 5: 278-293.

Edmeades, D.C.; Smart, C.E.; Wheeler, D.M.; Rys, G. 1983. Effects of lime on the chemical composition of ryegrass and white clover grown on a yellow brown loam. New Zealand Journal of Agricultural Research 26: 473-481.

Elliot, R.M. 1997. Interaction of Caucasian clover rhizobia with white clover. $\mathrm{PhD}$ Thesis, Otago University.

Gault, R.R.; Brockwell, J. 1980. Studies on seed pelleting as an aid to legume inoculation. 5. Effects of incorporation of molybdenum compounds in the seed pellet on inoculant survival, seedling nodulation and plant growth of lucerne and subterranean clover. Australian Journal of Experimental Agriculture and Animal Husbandry 20: 63-71.

Gaur, Y.D.; Lowther, W.L. 1980. Distribution, symbiotic effectiveness and fluorescence antibody reaction of naturalised populations of Rhizobium trifolii in Otago soils. New Zealand Journal of Agricultural Research 23: 529-532.

Gaur, Y.D.; Lowther, W.L. 1982a. Competitiveness and persistence of introduced rhizobia on oversown clover: influence of strain, inoculation rate and lime pelleting. Soil Biology Biochemistry 14: 99-102.

Gaur, Y.D.: Lowther, W.L. 1982b. Competition and persistence of strains of Rhizobium trifolii in relation to inoculation and lime pelleting on white clover sown in cultivated soil. New Zealand Journal of Agricultural Research 25: 277-280.
Gibson, A.H.; Curnow, B.C.; Bergersen, F.J.; Brockwell, J.; Robinson, A.C. 1975. Studies of field populations of Rhizobium: effectiveness of strains of Rhizobium trifolii associated with Trifolium subterraneum L. pastures in south-eastern Australia. Soil Biology Biochemistry 7: 95-102.

Gould, G.J.; Ludecke, T.E.; Parle, J.N. 1968. Establishment of oversown white clover on unimproved North Auckland clay hill country. Proceedings of the New Zealand Grassland Association 29: 88-95.

Greenwood, R.M. 1961. Pasture establishment on a podzolised soil in Northland. III. Studies on rhizobial populations and the effects of inoculation. New Zealand Journal of Agricultural Research 4: 375389.

Greenwood, R.M. 1965. Populations of rhizobia in New Zealand soils. Proceedings of the New Zealand Grassland Association 26: 95-101.

Hale, C.N. 1980. Competition between strains of Rhizobium trifolii in the establishment of white clover. Proceedings of the New Zealand Grassland Association 41: 138-145.

Hale, C.N. 1981. Methods of white clover inoculation, their effect in competition between naturalised and inoculated strains of Rhizobium trifolii. New Zealand Journal of Experimental Agriculture 9: 169-172.

Hale, C.N.; Lowther, W.L.; Lloyd, J.M. 1979. Effect of inoculant formulation on survival of Rhizobium trifolii and the establishment of oversown white clover (Trifolium repens). New Zealand Journal of Experimental Agriculture 7: 311-314.

Harrison, S.P.; Young, J.P.W.; Jones, D.G. 1989. Rhizobium population genetics; host preference and strain competition effects on the range of Rhizobium leguminosarum biovar trifolii genotypes isolated from natural populations. Soil Biology and Biochemistry 21: 981-986.

Hastings, A.; Drake, A.D. 1962. Pelleting inoculated clover seed. New Zealand Journal of Agriculture 104: 330-333.

Hastings, A.; Drake, A.D. 1963. Pelleted inoculated clover seed aids pasture establishment on problem soils. New Zealand Journal of Agriculture 106: 463468.

Holding, A.J.; King, J. 1963. The effectiveness of indigenous populations of Rhizobium trifolii in relation to soil factors. Plant and Soil 18: 191-198.

Ireland, J.A.; Vincent, J.M. 1968. A qualitative study of competition for nodule formation. pp 85-93 In: Transactions of the 9 th Congress of Soil Science. 
Lipsett, J.; David, D.J. 1977. Amount and distribution of molybdenum in a bag of molybdenised superphosphate. Journal of the Australian Institute of Agricultural Science 43: 149-151.

Loneragan, J.F.; Dowling, E.J. 1958. The interaction of calcium and hydrogen ions in the nodulation of subterranean clover. Australian Journal of Agricultural Research 9: 464-472.

Loneragan, J.F.; Meyer, D.; Fawcett, R.G.; Anderson, A.J. 1955. Lime pelleted clover seeds for nodulation on acid soils. Journal of the Australian Institute of Agricultural Science 21: 264-265.

Lowther, W.L. 1974a: Problems with clover inoculants in New Zealand. In: Proceedings 5th Australian Legumes Nodulation Conference.

Lowther, W.L. 1974b. Interaction of lime and seed pelleting on the nodulation and growth of white clover I. Glasshouse trials. New Zealand Journal of Agricultural Research 17: 317-325.

Lowther, W.L. 1975a. Interaction of lime and seed pelleting on the nodulation and growth of white clover II. Oversown trials. New Zealand Journal of Agricultural Research 18: 357-360.

Lowther, W.L. 1975b. Pelleting materials for oversown clover. New Zealand Journal of Experimental Agriculture 3: 121-125.

Lowther, W.L. 1977. Factors affecting the response of clover establishment to inoculation and pelleting. Proceedings of the New Zealand Grassland Association 38(1): 175-181.

Lowther, W.L. 1987. Application of molybdenum to inoculated, lime-coated white clover seed. New Zealand Journal of Agricultural Research 15: 271275.

Lowther, W.L.; Bonish, P.M. 1980. Field evaluation of commercially pelleted clover seed. New Zealand Journal of Experimental Agriculture 8: 249-253.

Lowther, W.L.; Johnstone, P. 1978. Effect of strain of Rhizobium trifolii on the establishment of oversown white clover (Trifolium repens). Soil Biology Biochemistry 10: 293-295.

Lowther, W.L.; Johnstone, P. 1979. Coating materials for commercial inoculated and coated clover seed. New Zealand Journal of Agricultural Research 22: 475-478.

Lowther, W.L.; McDonald, I.R. 1973. Inoculation and pelleting of clover for oversowing. New Zealand Journal of Experimental Agriculture 1: 175-179.

Lowther, W.L.; Patrick, H.N. 1993. Spread of Rhizobium and Bradyrhizobium in soil. Soil Biology and Biochemistry 25: 607-612.

Lowther, Bill; Patrick, Heather 1994. Legume inoculation and pelleting. AgResearch Information. New Zealand Pastoral Agriculture Research Institute Ltd.
Ludecke, T.E.; Leamy, M.L. 1972. Fertiliser use and grassland improvement on Central Otago hill and mountain soils. Tussock Grasslands and Mountain Lands Institute Review 25: 14-21.

Macfarlane, M.J.; Bonish, P.M. 1986. Oversowing white clover into cleared and unimproved North Island hill country - the role of management, fertiliser, inoculation, pelleting and resident rhizobia. Proceedings of the New Zealand Grassland Association 47: 43-51.

Materon, L.A.; Hagedorn, C. 1982. Competitiveness of Rhizobium trifolii strains associated with red clover (Trifolium pratense L.) in Mississippi soils. Applied and Environmental Microbiology 44: 1096-1101.

Newbould, P.; Holding, A.J.; Davies, G.J. 1982. The effect of Rhizobium inoculation on white clover in improved hill soils in the United Kingdom. Journal of Agricultural Science, Cambridge 99: 591-610.

Nutman, P.S. 1969. Symbiotic nitrogen fixation: legume nodule bacteria. pp. 179-181 In: Rothamsted Report for 1968. Part 2.

Pankhurst, C.E.; Greenwood, R.M. 1983. Establishment and persistence of Rhizobium trifolii in a developed soil. New Zealand Journal of Experimental Agriculture 11: 165-169.

Patel, J.J.; Lambert, M.G. 1985. Symbiotic effectiveness of root nodule bacteria isolated from white clover growing in North Island hill pastures. New Zealand Journal of Experimental Agriculture 13: 215-218.

Pryor, H. N.; Crush J. R. 2006. Elevated populations of effective rhizobia in the rhizoplane of white clover growing in pasture. New Zealand Journal of Agricultural Research 49: 85-87.

Reynolds, D. G. 1957: Improvement of high-country tussock land in the Omarama district. New Zealand Journal of Agriculture 94: 132-133.

Roughley, R.J.; Blowes, W.M.; Hurridge, D.F. 1976. Nodulation of Trifolium subterranean by introduced rhizobia in competition with naturalized strains. Soil Biology Biochemistry 8: 403-407.

Rys, G.J.; Bonish, P.M. 1981. Effectiveness of Rhizobium trifolii populations associated with Trifolium species in Taranaki, New Zealand. New Zealand Journal of Experimental Agriculture 9: 327-335.

Saxby, S.H. 1940. Grasses and clovers of New Zealand. Clovers are key to high production. New Zealand Journal of Agriculture 60: 272-276.

Saxby, S.H. 1956. Pasture production in New Zealand. New Zealand Department of Agriculture Bulletin 250.

Scott, D.; Archie, W.J. 1978. Sulphur, phosphate, and molybdenum coating of legume seed. New Zealand Journal of Agricultural Research 21: 643-649. 
Scott, R.S.; Grigg, J.L. 1970. Studies into the spatial distribution of fertiliser and seed applied from light aircraft. II. Recovery on the ground and efficiency of use of unevenly distributed fertiliser. New Zealand Journal of Agricultural Research 13: 12-32.

Sears, P.D.; Hyde, E.O.C.; Greenwood, R.M. 1955. Pasture establishment in pumice soil. New Zealand Journal of Science and Technology A37: 110-140.

Sewell, T. G. 1950: Improvement of tussock grassland. New Zealand Journal of Agriculture 81: 293-299.

Sewell, T. G. 1952: Tussock grassland investigations. Proceedings of the New Zealand Grassland Association 14: 123-137.

Sherwood, M.T.; Masterson, C.L. 1974. Importance of using the correct test host in assessing the effectiveness of indigenous populations of Rhizobium trifolii. Irish Journal of Agricultural Research 13: 101-108.
Smeatham, M.L. 1966. Steep tussock country in Central Otago can be improved. New Zealand Journal of Agriculture 113: 50-53.

Taylor, G.G.; Lloyd, J.M. 1968. Factors affecting survival of rhizobia on inoculated clover seed. Proceedings of the New Zealand Grassland Association 30: 154-163.

Watson, R.N. 1990. Effects of plant nematodes and Acremonium endophyte on white clover establishment with ryegrass or tall fescue. Proceedings New Zealand Weed and Pest Control Conference 43: 347-351.

Weaver, R.W.; Frederick, L.R. 1974. Effect of inoculum rate on competitive nodulation of Glycine $\max \mathrm{L}$. Merill. I. Glasshouse studies. Agronomy Journal 66: 229-232.

White, J.G.H. 1966. Introducing clovers into tussock country. Canterbury Chamber of Commerce Agricultural Bulletin No. 436. 
